\title{
Measuring Firm Smart Business Capability: a Total Capability Perspective
}

\author{
Chui Young Yoon
}

\begin{abstract}
Firms has rapidly been changed their business environment with developing a variety of IT technologies. Enterprises are making an effort for effectively applying them to their management activities in order to raise their business performance. With developing smart information technology, the smart business (SB) capability of a firm is very critical for the efficient execution of its management activities and to improve the performance of business tasks in a global business environment. The measurement and management for a firm SB capability need to efficiently establish and improve SB environment appropriate for its management strategy and business departments. A comprehensive instrument is necessary for efficiently measuring firm's SB capability to manage and improve its SB capability. The developed 12-item scale is verified based on previous literature. This study provides a 12-item instrument that can reasonably measure a firm SB capability in a total SB capability perspective.
\end{abstract}

Keywords - smart business, firm smart business capability, measurement factors and items, Structural instrument

\section{Introduction}

Many enterprises are performing their management activities and business tasks with partially and fully utilizing smart device, network, solutions and systems in a smart business environment [1 - 4]. Most firms have built smart business capability to increase their task performance and to improve their competitiveness in a global business environment. Enterprises are also applying smart technology to the management and business activities for improving their business performance. Smart business technology is an important means to improve and preserve a firm's task performance in the ever-changing business environment. It is indispensable to apply Smart business technology to the management activities and business tasks of an enterprise. Firm smart business capability has to be gauged by a scientific and practical and should be improved by objective criteria based on the analysis results. But a scientific and practical instrument to analyze a firm Smart business capability has not been studied in previous literature. Namely, we need a comprehensive and objective instrument that can effectively analyze an enterprise SB capability in terms of its entire Smart business ability.

Therefore, this study focuses on developing a structural instrument that can efficiently measure an enterprise Smart business capability for effectively performing Smart business tasks and smart management activities, and for systematically establishing and improving its Smart business environment in terms of a total Smart business capability.

Chui Young Yoon/ Department of IT Applied-Convergence

Korea National University of Transportation

Republic of Korea (South Korea)

\section{Previous Research}

Enterprises has partially or fully built smart business environment to perform their management activities and business tasks in a global business environment. Smart business can be described as a business process that uses the smart technology medium as a conduit to fulfill business transactions. Smart business can be defined as an approach to raise the competitiveness of organizations by improving management activities through using smart technology such as smart devices, networks, and solutions [1 - 4].

Hence, smart business (SB) can be defined as an approach to efficiently perform the firm's management activities by applying the smart technology and solutions, and systems to its business tasks and activities in a global business environment.

Many studies defined the concepts of IT capability from the view points of the studies' researchers [5 - 8]. But SB capability has rarely researched in previous literature. IT capability is considered the culmination of the sets of hardware, software, services, management practices, and technologies and management skills related to IT departments [12]. IT capability is explained as the ability to integrate other resources of an organization through the use and disposition of one's own IT resources. IT capability is formed by IT system convention, IT infrastructure, human IT resources, and IT relationship assets based on these resource-based perspectives. IT capability is conceptualized as the extent to which a firm is knowledgeable about and effectively utilizes IT technology to manage IT data within the firm $[9,10,12]$. The components of IT capability represent three co-specialized resources: IT objects; IT knowledge; and IT operations [9, 10, 12]. IT objects represent computer-based hardware, software, and support personnel. IT knowledge is conceptualized as the extent to which a firm possesses a body of technical knowledge about objects such as computer based systems. IT operations are identified as the extent that a firm utilizes IT to manage market and customer information [9, 10, 12].

From an information system maturity system perspective, the measurement of the information system level indicates the total capability that includes information system vision, information system infrastructure, information system support, and information system application and usage [13 - 16]. The information system vision presents an information system strategy plan and information system project plan of an enterprise. The information system infrastructure includes hardware, networks, system software, and supporting tools. information system support means information system organization, information system direction and institution, and supporting methods for information system facilities. Finally, the information system application and usage refer to the application and users that exploit solutions and information system for a firm's business tasks. SB capability 
is able to transform IT capability into a type of firm capability based on a smart business capability perspective.

Therefore, this research defines the firm smart business capability (FSC) as the total SB capability that a firm has to retain to efficiently support its management activities and perform SB tasks in a global management environment. We develop the first measurement items for FSC based on the definition of FSC and previous studies related to a firm SB capability.

\section{Methods}

\section{A. Research Method}

This research generated an initial list of 24 measurement items for FSC based on definitions and components of IT capability [1 - 16]. The developed measurement items were reviewed and refined by the expert group in our IT research center. The refined 24 measurement items are provided in Appendix A. We analyzed the construct validity of the developed items to ensure that FSC is efficiently measured by the items. This was proved by presenting that the instrument was a suitable operational definition of the construct it purported to measure. Many studies presented various methods to verify the validation of a model construct [17 - 22]. Generally, most studies present two methods of construct validation: (1) correlations between total scores and item scores, and (2) factor analysis [18 22].

In this research, the analysis questionnaire used a fivepoint likert-type scale as presented in previous studies; denoting, 1: not at all; 2: a little; 3: moderate; 4: good; and 5: very good. The survey was gathered data from a variety of industries, business departments, experience, and education. We performed two kinds of survey methods: direct collection and e-mail. The respondents either directly mailed back the completed questionnaires or research assistants collected them 2-3 weeks later. The collected questionnaires represented $38 \%$ of the respondents.:

\section{B. Sample Characteristics}

In this questionnaire survey, we collected 142 responses form 153 respondents. They represented a variety of industries, enterprises, business departments and positions, and experience. We excluded eleven incomplete or ambiguous questionnaires, leaving 142 usable questionnaires for statistical analysis. All respondents had college or university degrees in: humanities and societies $(18.3 \%)$, management and economics $(26.7 \%)$, engineering $(40.3 \%)$, and science $(14.7 \%)$. The respondents in terms of business departments were identified as strategy planning (20.4\%), development and maintenance (16.9\%), business application $(28.2 \%)$, and administration support (34.5\%). The respondents had on average 10.9 years' experience (S.D. $=1.06)$ in their field, their average age was 37.3 years old (S.D.=6.02), and $73 \%$ were male. This survey was intentionally focused on various industries and persons working above the 10 years within their firms. Namely, the respondents could efficiently provide the correct responses for our questionnaire survey.

\section{Analysis and Discussion}

This research extracted the analysis results from the collected questionnaires. After factor analysis and reliability analysis, the first 24 measurement items were reduced to 12 items, with 12 items were deleted, with applying the criterion of previous studies [19-21]. The elimination was sufficiently considered to ensure that the retained items were adequate analysis items of FSC. Each of the 12 items had a factor loading $>0.617$. The reliability coefficients (Cronbach's alpha) of four potential factors had values $>$ 0.797 as indicated in Table I, above the threshold recommended for exploratory research $[19-21]$. This research calculated the corrected item-total correlations between each variable and its corresponding factor in order to investigate the reliability and validity of the measurement items.

TABLE I. RELIABILITY, VALIDITY, AND FACTOR LOADINGS OF FSC CONSTRUCT

\begin{tabular}{|c|c|c|c|c|c|c|}
\hline \multirow{2}{*}{ Variable } & \multicolumn{4}{|c|}{ Factor Loading } & \multirow{2}{*}{$\begin{array}{l}\text { Corrected } \\
\text { Item-Total } \\
\text { Correlation }\end{array}$} & \multirow{2}{*}{$\begin{array}{c}\text { Coefficients } \\
\text { Alpha }\end{array}$} \\
\hline & Factor 1 & Factor 2 & Factor 3 & Factor 4 & & \\
\hline V03 & 0.771 & & & & 0.613 & \multirow{3}{*}{0.797} \\
\hline V04 & 0.806 & & & & 0.639 & \\
\hline V07 & 0.815 & & & & 0.609 & \\
\hline V10 & & 0.728 & & & 0.723 & \multirow{3}{*}{0.809} \\
\hline V12 & & 0.775 & & & 0.714 & \\
\hline V14 & & 0.829 & & & 0.761 & \\
\hline V15 & & & 0.817 & & 0.707 & \multirow{3}{*}{0.812} \\
\hline V16 & & & 0.751 & & 0.719 & \\
\hline V18 & & & 0.686 & & 0.691 & \\
\hline V20 & & & & 0.767 & 0.656 & \multirow{3}{*}{0.801} \\
\hline V23 & & & & 0.809 & 0.734 & \\
\hline V24 & & & & 0.617 & 0.629 & \\
\hline
\end{tabular}

We considered sufficiently high criteria to extract reasonable analysis items of FSC. These coefficients indicate the relative contribution of a measurement item for the construction of a scale to gauge a particular factor. Most corrected item-total correlations were greater than 0.609 , showing that the measurement items are good indicators of their corresponding factors. The extracted items have a validity and reliability in terms of a measurement construct based on the measurement results as presented in Table I. These results may be successfully achieved by accumulating many research findings and case studies. Through reflecting the measurement results of case studies, the developed measurement instrument can be became more objective and practical scale in the application of industrial fields. These deletions resulted in an 12-item scale to measure FSC. One factor with Eigen value $=8.1$ explained as explaining $67 \%$ of the variance.

\section{Structural Instrument of FSC}

The extracted 12 items were appropriate for measuring FSC. They were classified into four factor groups based on the factor analysis. The factor groups indicate the potential factors as major components to gauge FSC. By investigating the measurement items of each factor group based on 
previous studies, we identified the following four potential factors: factor 1: SB plan; factor 2: SB knowledge; factor 3: SB application; and factor 4: SB resource. These extracted factors include the overall measurement content for FSC from SB plan to SB resource. SB plan presents a firm's consistent SB policy. It includes SB plan and program, consentaneity between SB plan and management plan, and SB implementation plan, to effectively develop FSC. SB knowledge indicates the technical knowledge that a firm has to retain such as SB technology, SB solutions and applications, and SB security systems. SB application indicates a firm's ability to apply SB knowledge, SB solutions and applications, SB systems to management activities to efficiently execute the firm's business activities. SB resource means SB infrastructure, such as SB systems, networks and solutions, personnel to maintain and manage SB systems, and SB security systems. That is, this refers to a structural instrument that can measure FSC in terms of a total SB capability from SB plan to SB resource, including four measurement factors and 12 items.

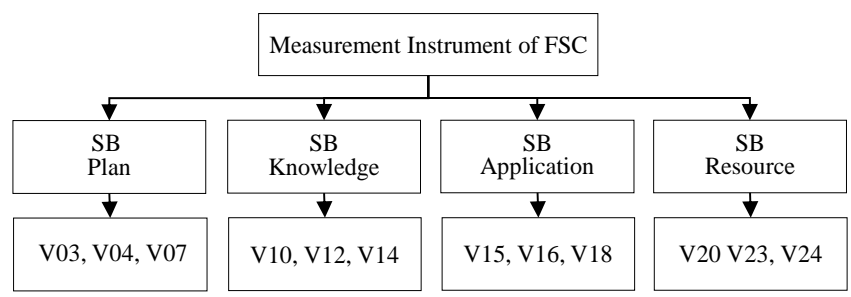

SB Plan (SBP)

V03: Consentaneity between SB plan and management plan

V04: Establishment of SB strategy and plan to improve SB environment

V07: Establishment of detailed implementation program for SB plan

SB Knowledge (SBK)

V10: solution knowledge related to B2E, B2C, and B2B etc.

V12: Knowledge of H/W, S/W, N/W and D/B related to SB systems

-V14: Knowledge related to SB security solutions and systems

SB Application (SBA)

V15: Application of H/W, S/W, N/W, and D/B to SB systems

V16: Application of SB solutions and systems to B2E, B2C, and B2B

V18: Application of security measures and systems to SB

SB Resource (SBR)

V20: Possession of information systems appropriate to SB management activities

V23: Possession of intellectual property related to SB

V24: Possession of SB security measures and systems

Figure 1. The developed measurement instrument for FSC

Hence, the developed instrument comprises four measurement factors such as SB plan, SB knowledge, SB application, and SB resource as shown in Fig. 1. As presented in Table I and Fig. 1, SB plan includes the measurement items, such as V03, V04, and V07. SB knowledge has V10, V12, and V14. SB application comprises V15, V16, and V18. SB resource consists of V20, $\mathrm{V} 23$, and V24. These factors affect FSC, that is, the total SB capability of a firm. It is important to improve and manage FSC by measuring a firm's SB capability with a valid and reliable instrument. Using this instrument can facilitate efficiently raising a firm's SB capability. Measuring FSC is a critical method to examine the total SB ability of a firm, based on its SB plan, SB knowledge, SB application, and SB resource.

Therefore, understanding the FSC construct is essential to measure the success of FSC that denotes the total SB capability to efficiently support its management activities. This research can use the instrument to gauge FSC across different industrial fields and business departments, and perhaps even as a global measure.

\section{v. Conclusion}

This research provided a structural instrument that can measure perceived FSC from a total SB perspective. Perceived FSC indicates a firm's total SB capability to effectively perform its management activities and business tasks in a global business environment. The developed instrument with adequate validity and reliability presents groundwork for the development of a standard framework to gauge FSC.

Therefore, this study presents a structural instrument that can efficiently measure FSC to efficiently perform a firm's management activities and improve their performances and competitiveness in a global management environment. This instrument can be also supported to effectively build a firm's SB capability appropriate for its management activities and business tasks. In future research, we will find the practicality and availability of this measurement instrument with providing the analysis results by applying it to a case study.

\section{Acknowledgment}

This research was supported by Basic Science Research Program through the National Research Foundation of Korea (NRF) funded by the Ministry of Education, Science and Technology (NO: 2013R1A1A2012350).

\section{Appendix A. Measurement items for firm smart business capability}

1. Establishment of smart business strategy plan and program

2. Performance analysis between smart business investments and effects

3. Consentaneity between smart business plan and management plan

4. Establishment of smart business strategy and plan to improve smart business environment

5. Understanding of smart business trends in future

6. Understanding of big data and cloud computing in oversea and domestic fields

7. Establishment of detailed implementation program for smart business plan

8. Understanding of smart business of personnel working in organization

9. Solution technology related to ERP, SCM, CRM and KMS for smart business etc.

10. Solution knowledge related to $\mathrm{B} 2 \mathrm{E}, \mathrm{B} 2 \mathrm{C}$, and $\mathrm{B} 2 \mathrm{~B}$ for smart business

11. Technology of smart business networks and solutions?

12. Knowledge of $\mathrm{H} / \mathrm{W}, \mathrm{S} / \mathrm{W}, \mathrm{N} / \mathrm{W}$, and D/B related smart business systems 
13. Technical knowledge of big data and cloud technology for smart business

14. Knowledge related to smart business security solutions and systems

15. Application of $\mathrm{H} / \mathrm{W}, \mathrm{S} / \mathrm{W}, \mathrm{N} / \mathrm{W}$ and $\mathrm{D} / \mathrm{B}$ to smart business systems

16. Application of smart business solutions and systems to $\mathrm{B} 2 \mathrm{E}, \mathrm{B} 2 \mathrm{C}$, and B2B etc.

17. Application of big data and cloud technology to smart business

18. Application of security measures and systems to smart business

19. Utilization of executive smart business systems?

20. Possession of smart business systems appropriate to smart management activities

21. Possession of patents related to smart business department

22. Possession of network and solutions appropriate to smart business management

23. Possession of intellectual property related to smart business

24. Possession of smart business security measures and systems

\section{References}

[1] E. V. Heck, and P. Vervest, "Smart business networks: Concepts and empirical evidence", Decision Support Systems, vol. 47, pp. 275-276, 2009

[2] L. M. Hilty, B. Aebischer, A. Rizzoli, "Modeling and evaluating the sustainability of smart solutions", Environmental Modeling \& Software, vol. 56, pp. 1-5, 2014

[3] J. Busquets, J. Rodon, and J. Wareham, "Adaptability in smart business networks: An exploratory case in the insurance industry", Decision Support Systems, vol. 47, pp. 287-296, 2009.

[4] Y. F. Chang, C. S. Chen, and H. Zhou, "Smart phone for mobile commerce", Computer Standards \& Interfaces. vol. 31, pp. 740-747, 2009.

[5] C. Y. Yoon, "Development of a Measurement Model of Personal Information Competency in Information Environment", The Korea Society of Information Processing and Systems, vol. 14-D, pp. 131138, 2007.

[6] C. S. Leem, and S. K. Kim, "Introduction to an integrated methodology for development and implementation of enterprise information systems", The Journal of Systems and Software, vol. 60, pp. 249-261, 2002.

[7] A. S. Bharadwaj, "A resource-based perspective on information technology capability and firm performance: an empirical investigation”, MIS Quarterly, vol. 24, pp. 169-196, 2000.

[8] H. Jiao, C. Chang, and Y. Lu, "The Relationship on Information Technology Capability and Performance: An Empirical Research in the Context of China's Yangtze River Delta Region”, Proceeding of The IEEE International Conference on Industrial Engineering and Engineering Management, pp. 872-876, 2008

[9] IBM Research Report, Business Services as a Modeling Approach for Smart Business Networks, www.ibm.com, June 2, 2006.

[10] IT Policy Research Series, "Issue and Business Trend Change of Smart Era", vol. 3, pp. 1-13, www.nia.or.kr, 2011.

[11] H. K. Jang, "Change of Paradigm of Firm Business Environment provided by Smart Phone", DigiEco Focus, www.digieco.co.kr, 2010.

[12] M. Gibbert, M. Leibold, and G. Probst, "Five Styles of Customer Knowledge Management, and How Smart Companies Use Them To
Create Value", European Management Journal, vol. 20, pp. 459-469, 2002.

[13] H. J. Lee, "A Study on the Business Strategy of Smart Devices for Multimedia Contents", Journal of Information Processing Systems, vol. 7, pp. 543-548, 2011.

[14] F. Gabbanini, L. Burzagli, and P. L. Emiliani, "An innovative framework to support multi-model interaction with smart environments", Expert Systems with Applications, vol. 39, pp. 22392246, 2012.

[15] S. H. Lee, H. O. Do, and K. D. Seo, "A Study on Management Plans for Activating of Smart Work", Digital Policy Research, vol. 9, pp. 245-252, 2011.

[16] T. G. Lee, "Smart Manufacturing Execution System and Business Intelligence", Journal of Korea Institute of Information Technology, vol. 9, pp. 35-43, 2010.

[17] F. N. Kerlinger, Foundations of Behavioral Research, McGraw-Hill, New York, 1978

[18] W. J. Doll, and G. Torkzadeh, "The Measurement of End-user's Information Satisfaction", MIS Quarterly, vol. 12, pp. 982-1003, 1988 .

[19] J. Etezadi-Amoli and A. F. Farhoomand, "A Structural Model of End User Information Satisfaction and User Performance", Information \& Management, vol. 30, pp. 65-73, 1996.

[20] G. Torkzadeh and W. J. Doll, "The Development of a Tool for Measuring the Perceived Impact of Information Technology on Work", Omega, International Journal of Measurement Science, vol. 27, pp. 327-339, 1999.

[21] G. Torkzadeh and J. W. Lee, "Measures of Perceived End-user's Information Skills", Information \& Management, vol. 40, pp. 607 615, 2003.

[22] R. McHancy, R. Hightower, and J. Pearson, "A validation of end-user computing satisfaction instrument in Taiwan", Information \& Management, vol. 39, pp. 503-511, 2002.

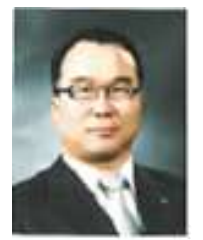

Chui Young Yoon received the Ph.D. degree in Computer Science \& Industrial System Engineering from Yonsei University, South Korea in 2003. He worked as a professor at Seoul Cyber University for 2003-2005, School of Electrical \& Computer Engineering in Chungbuk National University for 20062011, and now works at Department of IT Applied-Convergence in Korea National University of Transportation, South Korea. His research interests include information system, e-Business, computing application, human-computer interaction, web-based system, smart business technology, and ubiquitous technology. 